\title{
Nancy Plankey-Videla: We Are in This Dance Together: Gender, Power, and Globalization at a Mexican Garment Firm
}

\section{Citation}

Dobbin, Frank. 2013. “Nancy Plankey-Videla: We Are in This Dance Together: Gender, Power, and Globalization at a Mexican Garment Firm." Administrative Science Quarterly (June 3). doi:10.1177/0001839213493887. http://dx.doi.org/10.1177/0001839213493887.

\section{Published Version}

doi:10.1177/0001839213493887

\section{Permanent link}

http://nrs.harvard.edu/urn-3:HUL.InstRepos:11644068

\section{Terms of Use}

This article was downloaded from Harvard University's DASH repository, and is made available under the terms and conditions applicable to Other Posted Material, as set forth at http:// nrs.harvard.edu/urn-3:HUL.InstRepos:dash.current.terms-of-use\#LAA

\section{Share Your Story}

The Harvard community has made this article openly available.

Please share how this access benefits you. Submit a story.

\section{Accessibility}




\title{
Administrative Science Quarterly
}

Nancy Plankey-Videla: We Are in This Dance Together: Gender, Power, and Globalization at a Mexican Garment Firm

Frank Dobbin

Administrative Science Quarterly published online 3 June 2013

DOI: $10.1177 / 0001839213493887$

The online version of this article can be found at:

http://asq.sagepub.com/content/early/2013/05/31/0001839213493887

\author{
Published by: \\ (SAGE \\ http://www.sagepublications.com
}

On behalf of:
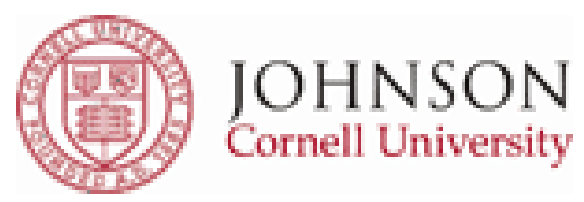

Johnson at Cornell University

Additional services and information for Administrative Science Quarterly can be found at:

Email Alerts: http://asq.sagepub.com/cgi/alerts

Subscriptions: http://asq.sagepub.com/subscriptions

Reprints: http://www.sagepub.com/journalsReprints.nav

Permissions: http://www.sagepub.com/journalsPermissions.nav

> OnlineFirst Version of Record - Jun 3, 2013

What is This? 
Nancy Plankey-Videla: We Are in This Dance Together: Gender, Power, and Globalization at a Mexican Garment Firm. New Brunswick, NJ: Rutgers University Press, 2012. 259 pp. \$72.00, cloth; \$25.95, paper.

In 2000, Nancy Plankey-Videla began an ethnography at a high-end men's suit factory in central Mexico. Three months later, reacting to layoffs, bonus cuts, and an effort to break the union contract, which managers blamed on global competition and the U.S. recession, the largely female workforce at Moctezuma went on strike. A corrupt union conspired with management and state regulators to put an end to the strike, but Plankey-Videla was in the right place at the right time to explore how the structure of work (five years earlier the plant replaced piecework with teamwork), the construction of gender (management articulated two constructions of the ideal female worker), and globalization (Mexico was hemorrhaging factory jobs) produced worker resistance. In the process, she explores how work structures create individualism and collectivism, how management manipulates gender roles to gain cooperation, and how globalization is refracted in local ideologies of work and class interest.

Globalization played an unexpected role. It produced price competition, to be sure, encouraging management to reduce labor costs. But by opening up ideological exchange through, for instance, networks of Mexican migrants, it also gave the women at Moctezuma new ideas about gender, collective interest, and power that enabled them to strike in the face of a threat to their livelihoods. Immigration to the U.S. now offered these women an alternative to factory work, even if it carried predictable perils. Meanwhile, media access made these women aware of social and labor movements across Mexico and showed them a route other than complacency.

The shift from piecework to teamwork might have been expected to cause workers to identify with management, for it made them responsible for their own output and directed their attention to cost and quality. Or it might have fostered class consciousness by bringing the women together on teams. Plankey-Videla tells a more nuanced story. The piecework system, characterized by high turnover, individuated work, and competition to maximize individual take-home pay, defined work as secondary to family for the women workers, who were single mothers, married women earning supplemental income, and young women living with their parents. Under teamwork, the role of mother remained the central identity of many of these workers. Thus selfmanaged work teams made allowances for mothers. At the same time, the teams built these women's managerial and organizational capabilities and forged connections across work groups that had to coordinate production together. In this way, teamwork created some of the conditions Marx identified 
as key to the rise of class consciousness. Yet resistance arose less through class consciousness than through a new "motherist" sensibility, which critiqued management for failing in its role as patriarch to the mothers working in the factory. Managers not only failed to make good on their promises of bonuses and stable employment, they went to court to break the union agreement. The women at Moctezuma did not resist because they saw their Marxian class interests, but because management had broken its own compact, based on a traditional, familial, and sexual division of labor. When management appealed to the women to accept the new working conditions so as to shield the weakest among them, single mothers, from destitution, leaders of the protest turned this argument on its head by arguing that management had failed in its patriarchal role. Only through the strike did the women's identities begin to change, from mothers-who-worked to workers-who-weremothers. They came to see themselves as citizens of the firm who deserved to find self-esteem, autonomy, and meaning in their work.

Plankey-Videla spent nine months working on the shopfloor at Moctezuma, with cooperation from the highest levels of management, the union, and the workers around her. She interviewed dozens of workers and managers and continued to reinterview them over the course of a decade. She kept extensive field notes and was given access to company records on over 1000 workers. She compiled a database of over 400 newspaper stories on the factory. These rich sources of evidence allow her to piece together not only the events surrounding the 2001 conflict but also the history of a 1972 strike at the same factory, the rise of a third management system after the 2001 conflict, and the demise of the factory.

While the narrative arc of the book concerns the precursors to the 2001 labor strike and the strike's aftermath, some of the most interesting insights come from the chapters detailing the transition to teamwork. Under the Taylorist, piecework system in place during the strike of 1972, we see many of the patterns that appear in other shopfloor ethnographies. Piece-rate workers hold the whip over themselves to maximize income, yet they game the system by hiding output from supervisors. After that system was replaced, they looked back on it fondly because it made them autonomous and enabled them to control the income they brought home. And in contrast to the teamwork system, they did not have to cajole their sisters to increase output; that was management's job.

In the mid-1990s the owners brought in consultants to design lean, Japanese-inspired, flexible production to meet changes in global demand. Teamwork was at the core of the new system. The chapter documenting this change is fascinating, for it shows how consultants not only redesigned production and trained workers and managers for teamwork but also redefined the ideal worker as a stable family woman over 25. The idea that women were docile and suited to detail work carried over from the previous depiction of the ideal worker, but now the factory depended on greater skill and workforce stability. The new ideal worker was dependent on the factory, invested in learning skills, and did not quit. Teamwork improved production by making workers feel that they were in a "community of fate," sharing success or failure with their teams. Bonuses depended on team performance, and so workers began to crack the whip to speed team members up. Teamwork systems have become 
widespread around the world, and Plankey-Videla's ethnography provides a much-needed look at the internal dynamics of one system.

The strike did not last long enough to undermine company profits, but the factory soon began to unravel. Whether it would have unraveled due to global competition, even without the failure of the new system that management put into place, is hard to know. But by the accounts of workers and managers alike, that system failed. Flexible Taylorism was to reduce the labor organizing opportunities created by teamwork while retaining the flexibility to adapt to changes in global demand. But the strike had sparked ongoing dissent, and when management replaced skilled movement leaders with unskilled novices, they undermined the production process. Moctezuma filed for bankruptcy by the end of the year.

We Are in This Dance Together joins a venerable tradition of workplace ethnographies and a more recent tradition of feminist ethnographies of factories in the developing world. Plankey-Videla offers a rich portrait of work in a changing global, and gender, environment. Her use of multiple sources of evidence allows her to color in the picture in fine detail. We are left with an intriguing depiction of how the organization of work shapes class consciousness and of how management can use traditional gender roles to build workers' identities and, at the same time, gain workers' cooperation. We also see how management can lose control of the workforce by losing control of the framing of work and identity. One of the great strengths of the book comes from a feature Plankey-Videla only mentions in passing: her status as an outsider, a highly educated Chilean American. Because she is a stranger, both managers and workers explain the obvious to her. Because she is an outsider, she takes little for granted in exploring Moctezuma and thus sketches for us not only the trees but the forest around them.

Frank Dobbin

Department of Sociology

Harvard University

Cambridge, MA 02138

frank_dobbin@harvard.edu 